Arch. Tierz., Dummerstorf 46 (2003) 2, 187-198

Research Institute for the Biology of Farm Animals, Department of Reproductive Biology, Dummerstorf, Germany

WILHELM KANITZ

\title{
Follicular dynamic and ovulation in cattle - a review
}

Dedicated to Prof. Dr. agr. habil. Dr. h. c. mult. Georg Schönmuth on the occasion of his $75^{\text {th }}$ birthday

\begin{abstract}
Summary
A review is given about follicular populations and aspects of follicular development in cattle. Ovaries of cattle contain two different pools of follicles, the non-growing pool and the growing pool. Entry of primordial follicles into the growth phase occurs throughout the reproductive life. Once follicles are recruited to grow, they are destined to undergo atresia or ovulation. Growth of obligatory gonadotropin-dependent follicles occurs in a wave like pattern. The growth waves are characterised by the processes of recruitment, selection and dominance. The known mechanisms responsible for these three processes are discussed.
\end{abstract}

Key Words: cattle, follicular populations, follicular dynamic

\section{Zusammenfassung}

Titel der Arbeit: Follikeldynamik und Ovulation beim Rind - eine Übersicht

Der Artikel gibt einen Überblick über Follikelpopulationen und Aspekte der Follikeldynamik beim Rind. In den Eierstöcken von Rindern existieren zwei Follikelpopulationen, die entweder dem ruhenden oder dem wachsenden Pool angehören. Während der reproduktiven Phase gehen ruhende Follikel in den wachsenden Pool über. Nachdem ein Follikel mit dem Wachstum begonnen hat, wird er entweder atretisch oder gelangt zur Ovulation. Das Wachstum der obligatorisch gonadotropinabhängigen Follikel erfolgt dabei in sogenannten Follikelreifungswellen. Diese sind durch die Prozesse der Rekrutierung, Selektion und Dominanz gekennzeichnet. Die Mechanismen und Faktoren, welche für die drei genannten Prozesse verantwortlich sind werden diskutiert.

Schlüsselwörter: Rind, Follikelpopulationen, Follikeldynamik

\section{Follicular populations}

Ovaries of cattle contain two different pools of follicles, the non-growing pool and the growing pool (Fig. 1). The non-growing pool contains the primordial follicles, whereas the growing pool contains the primary, secondary and tertiary follicles (KANITZ et al., 2001). Entry of primordial follicles into the growth phase occurs throughout the reproductive life. The primordial follicles continuously leave the arrested pool and undergo the primordial to primary follicle transition. The oocytes increase in size and the surrounding squamous pre-granulosa cells become cuboidal and proliferate to form a layer of cuboidal cells around the growing oocyte (FORTUNE et al., 2000). The follicle is called now a primary follicle. The mechanisms responsible for the initiation of follicular growth are poorly understood although some candidate molecules (gonadotropins, growth factors, $c$-kit) have been discussed (WEBB et al., 1999). In vitro studies with rat ovarian tissue showed that 
leukaemia inhibitory factor (LIF) and basic fibroblast growth factor (bFGF) are able to promote the primordial to primary follicle transition (NILSSON et al., 2001, 2002). But the finding that during culture of isolated bovine or primate ovarian cortex almost all primordial follicles activate and develop into primary follicles suggests that noncortical portions of the ovary may regulate the flow of follicles from the resting reservoir (FORTUNE et al., 1999). The number of follicles commencing growth in a given time is predictable because it is a function of the size of the primordial store, which declines exponentially with time (WEBB et al., 1999).

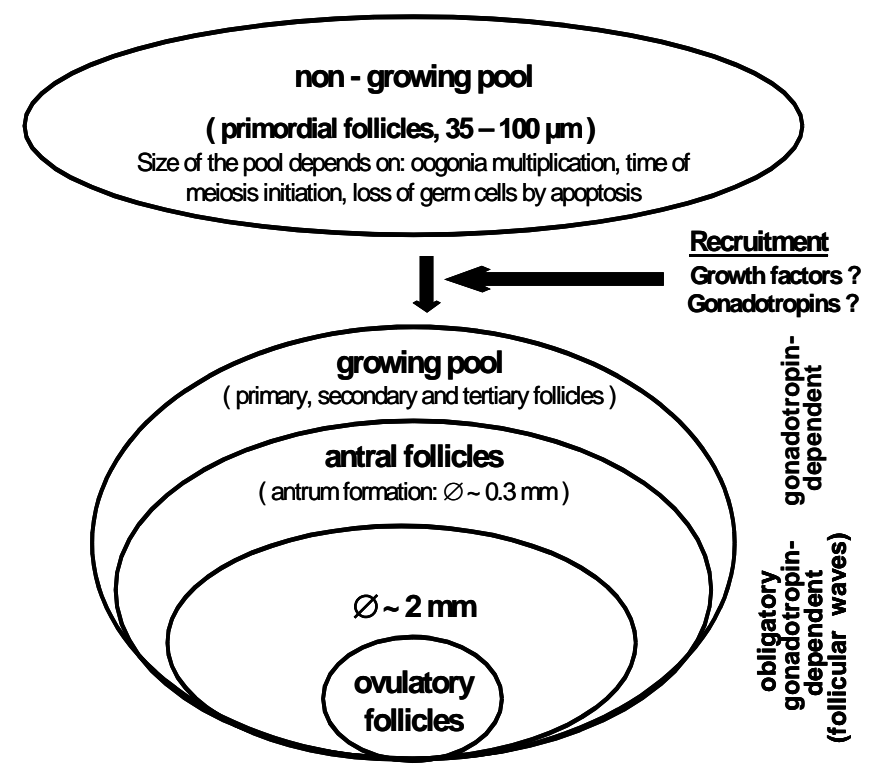

Fig. 1: Schematic diagram of follicular populations in cattle (Schematische Darstellung der Follikelpopulationen beim Rind)

During recruitment of follicles into the growing pool theca cells organize into distinct layers around early developing follicles and establish essential cell-cell interactions with granulosa cells. In this process granulosa cell-derived kit-ligand appears to promote the formation of theca cell layers around small (i.e., primary) ovarian follicles (PARROTT and SKINNER, 2000). In the process of theca cell differentiation cells become epitheloid and acquire organelles characteristic for steroid secreting cells.

Once follicles are recruited to grow, they are destined to undergo apoptosis unless rescued by survival factors (HSUEH et al., 1996). The Fas antigen and the Fas ligand system seem to play an important role in mediating apoptosis (PORTER et al., 2001).

\section{Follicular waves}

In cattle the growth of obligatory gonadotropin-dependent follicles occurs in a wave like pattern (DRIANCOURT, 2001). Waves of growth can be observed during the prepubertal period (ADAMS et al., 1994; EVANS et al., 1994; MELVIN et al., 1999), in pregnant cattle (TAYLOR and RAJAMAHENDRAN, 1991), in postpartum periods (MURPHY et al., 1990) and during oestrous cycles (ROCHE et al., 1999). During one interovulatory interval two (GINTHER et al., 1989; KNOPF et al., 1989; RAJAMAHENDRAN and TAYLOR, 1991; AHMAD et al, 1997, BURKE et al., 2000; BELLMANN 2001), three (SAVIO et al., 1988; SIROIS and FORTUNE, 1988; AHMAD et al., 1997, BURKE et al., 2000; BELLMANN, 2001) or four waves (RHODES et al., 1995) have been observed. Cycles with three waves were on average 
1.1 day longer and Corpora lutea regressed later than in animals with two waves. Moreover, interval from detection of dominant follicle to ovulation and duration of dominance were shorter in animals with three waves (AHMAD et al., 1997). ADAMS (1999) concluded from the available data that greater than $95 \%$ of oestrous cycles are composed of either two or three follicular waves.

Normally three to six follicles with a diameter of 4 to $5 \mathrm{~mm}$ occur after recruitment of follicles into in a follicular wave (SAVIO et al., 1988; SIROIS and FORTUNE, 1988; SUNDERLAND et al., 1994). However, the number of follicles, which are recruited in a wave seems to be higher (ADAMS, 1999; BELLMANN, 2001). From the cohort, one follicle is selected for continued growth and becomes dominant. If luteolysis occurs during the growth phase of dominant follicles, final maturation and ovulation occurs. If luteolysis does not occur during the growing and maintenance phase of follicles, the fate is atresia (Fig. 2).

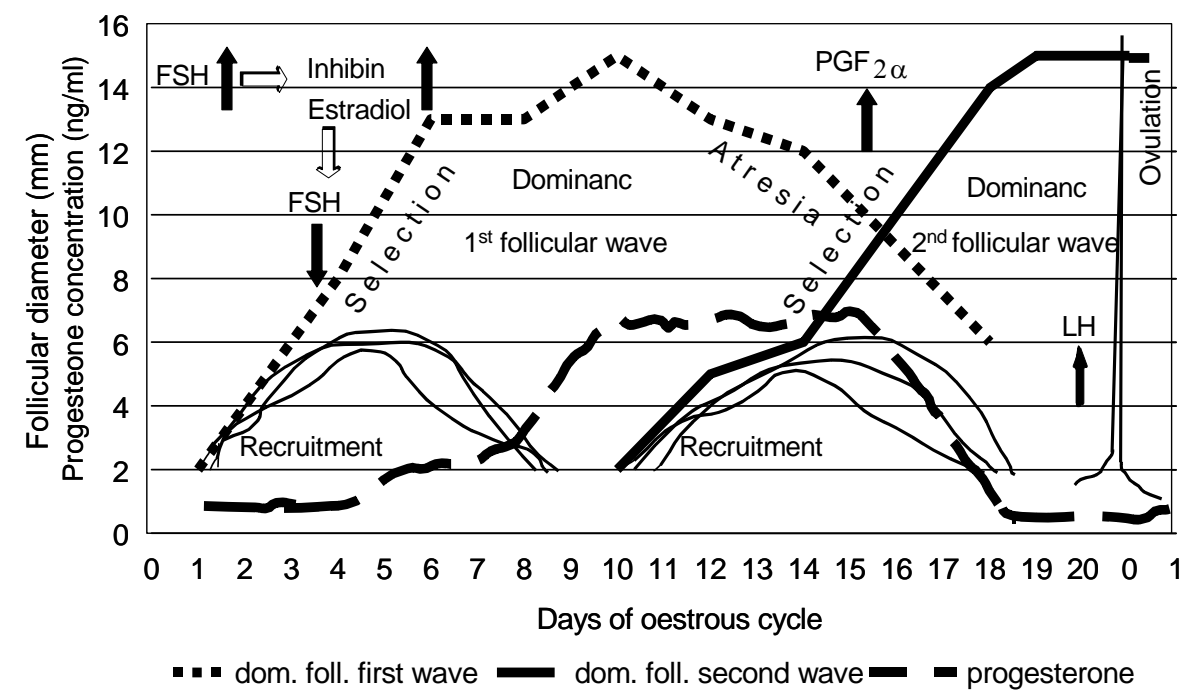

Fig. 2: Schematic diagram of events of follicular growth in waves during an interovulatory interval (Schematische Darstellung von Ereignissen in Follikelreifungswellen während eines Interöstrusintervalls)

Changes in mRNA expression for the gonadotropin receptors, key steroidogenic enzymes and growth factors (IGF-I and -II) and their binding proteins (IGFBP) have been associated with different stages of follicular growth and atresia. In general, expression of mRNA for the gonadotropin receptors, steroidogenic enzymes, and steroidogenic acute regulatory protein (StAR) increase with progressive follicular development and is highest when dominant follicles approach maximum size. Expression of mRNA declines rapidly and becomes low or undetectable in atretic follicles. The IGF-I (granulosa cells) and IGF-II (theca cells) are increased, whereas IGFBP-2 (granulosa cells) is reduced, in dominant follicles. Recruitment of a cohort of follicles is associated with initiation of expression of mRNA for P450scc and P450arom in granulosa cells. Selection of dominant follicles is associated with expression of mRNA for LH receptors and 3 $\beta$-HSD in granulosa cells. Thus, changes in gene expression likely are important to recruitment, selection, dominance, and atresia in ovarian follicles (BAO and GARVERICK, 1998; BEG et al., 2001, 2002). 
The concept recruitment is used for the entrance of follicles in the growing pool, but also for the processes associated with the entrance of follicles in a wave like growth pattern. FSH is the key hormone for the endocrine initiation of follicular wave occurrence (ADAMS et al., 1992; SUNDERLAND et al., 1994; FRICKE et al., 1997). ADAMS et al. (1992) found that two-wave heifers had two FSH surges and threewave heifers had three apparent FSH surges during the interovulatory interval. Results of the cautery and follicular fluid experiments indicated that a surge in FSH necessarily preceded the emergence of a wave. The FSH surges in treated and control heifers began 2 - 4 days before the detectable (ultrasound) emergence of a follicular wave (follicles of 4 and $5 \mathrm{~mm}$ ), peaked 1 or 2 days before emergence and began to decrease approximately when the follicles of a wave begin to diverge into a dominant follicle and subordinate follicles (follicles 6 - $7 \mathrm{~mm}$ ). GINTHER et al. (2000) found also that the surge reaches a peak by the time the follicles attain $4 \mathrm{~mm}$ in diameter. In accordance with this CROWE et al., (1998) observed that the emergence of each follicle wave postpartum was preceded by a 2- to 4-day rise in FSH concentrations. The pattern of FSH isoform distribution did not differ between the pre- and postpartum periods. As follicular recruitment proceeds, mRNA for P450 aromatase increases (FORTUNE et al., 2001).

\section{Selection}

Selection means that the number of growing follicles is brought into line with the species-specific ovulation number (FORTUNE, 1994). After recruitment fewer and fewer recruited follicles continue in growth until one follicle is selected to become dominant while the remaining members of the recruited follicles become static and undergo atresia via apoptosis.

The processes of selection occur under declining FSH concentrations and take 2 to 3 days (EVANS et al., 1997; AUSTIN et al., 2001). GIBBONS et al. (1999) found that Follicles $\leq 3 \mathrm{~mm}$ had no detectable capacity to suppress FSH. As follicles grew from 3 to $5 \mathrm{~mm}$, they gained the capacity to suppress FSH; however, as follicles grew beyond $5 \mathrm{~mm}$, FSH-suppressing capacity did not increase. At the beginning of selection all of the growing follicles $\geq 5 \mathrm{~mm}$ contribute to the decline in FSH concentrations (GIBBONS et al., 1997; GINTHER, 2000). These results of KANEKO et al. (1997) demonstrated that inhibin neutralization during the early luteal phase produces hypersecretion of FSH with a coincident stimulation of follicular development, indicating that inhibin is an important factor for the negative regulation of FSH secretion during the early luteal phase when secretion of estradiol and progesterone are normally high. Also GINTHER et al. (2001a) stated that inhibin is the primary FSH suppressant at this time. IRELAND and IRELAND (1994), IRELAND et al. (1994) and GOOD et al. (1995) observed multiple forms of inhibin/activin subunit mRNA and peptide in follicular tissue and fluid. AUSTIN et al. (2001) found that the dominant follicle maintains high amounts of higher molecular weight inhibins while the subordinate follicles have increased amounts of the smallest (34 kDa) inhibin.

KULIK et al. (1999) reported that deviation occurred when the 2 largest follicles were $8.3 \pm 0.2$ and $7.8 \pm 0.2 \mathrm{~mm}$ in diameter. This was observed at $61.0 \pm 3.7 \mathrm{~h}$ after wave emergence. Very similar data about follicular diameter at the time of deviation were reported by GINTHER et al. (2000). The authors found that the largest follicles reach 
means of 8.5 and $7.7 \mathrm{~mm}$ in diameter at the end of the selection period. Thereafter they begin to undergo deviation in diameters, which is characterized by continued growth of the largest follicle to become the dominant follicle and reduced or terminated growth of the remaining follicles to become subordinate follicles.

At the beginning of follicular deviation the largest follicle releases increased estradiol into the blood, and the released estradiol is involved in the continuing depression of FSH concentrations to below the requirement of the smaller follicles but not the largest follicle (GINTHER et al., 1999; 2000). In addition aspiration of the dominant follicle at any stage of the cycle affected circulating FSH but did not appear to influence the mean LH concentration (AMIRIDIS et al., 1999). GINTHER et al. (2001a) reported that apparently both estradiol and inhibin contribute to the continuing FSH decline from this time. Moreover it was found that elevated concentrations of LH and reduced concentrations of FSH were present 32 to $16 \mathrm{~h}$ before to at least $24 \mathrm{~h}$ after the beginning of follicle deviation GINTHER et al. (1998). The increased secretion of estradiol into the circulation and the increase in estradiol and IGF-I and decrease in IGFBP-2 concentrations in the follicular fluid at the start of deviation are functions of the transient increase in LH concentrations that encompasses follicle deviation GINTHER et al. (2001b). In heifers, receptors for LH appeared in the granulosa cells of the future dominant follicle about $8 \mathrm{~h}$ before the beginning of deviation. In addition, LH-receptor mRNA expression in the granulosa cell layer was limited to follicles that also expressed mRNAs for P450scc and P450arom in the granulosa cells (BAO et al., 1997). The LH stimulates the production of estradiol and insulin-like growth factor- 1 . These intrafollicular factors and perhaps others account for the responsiveness of the largest follicle to the low concentrations of FSH. The smaller follicles have not reached a similar developmental stage and because of their continued and close dependency on FSH become susceptible to the low concentrations (GINTHER et al., 2001a).

In the past decade, numerous intrafollicular growth factors, such as inhibins, activins, and insulin-like growth factors and their binding proteins, have been identified in follicular fluid of individual bovine follicles (CHAMBERLAIN and SPICER, 2001; MIHM et al., 2002; SCHAMS et al., 2002). The IGF stimulate ovarian function by acting synergistically with gonadotropins to promote growth and steroidogenesis of ovarian cells. Actions of IGF-I and -II are restrained by a series of IGF binding proteins (IGFBP) that either originate from the blood or are synthesized locally within the follicle. Degradation and differential synthesis of IGFBP are important mechanisms regulating IGFBP amounts. The relative amounts of IGFBP may ultimately determine ovarian IGF action (LUCY, 2000). MIHM et al. (2000) found that the future dominant follicle in most cohorts had the highest estradiol and lowest IGFBP-4 concentrations compared with future subordinate follicles. The authors concluded that IGFBP-4 and estradiol may have key roles in determining the physiological fate of follicles during selection of the first wave dominant follicle and that both are reliable markers to predict which follicle in a growing cohort of 5 to 8.5 $\mathrm{mm}$ follicles becomes dominant. In addition, maintenance of low amounts of intrafollicular IGFBP4 may constitute an important mechanism in the future DF to attain FSH independence (MIHM and AUSTIN, 2002; MIHM et al., 2002). In contrast to that atresia of subordinate follicles appears to be associated with increased expression of the IGFBP2 gene (YUAN et al., 1998). Results of BERISHA et al. 
(2000) suggest that VEGF and FGF families are involved in the proliferation of capillaries that accompanies the selection of the preovulatory follicle resulting in an increased supply of nutrients and precursors, and therefore supporting the growth of the dominant follicle.

In vitro studies complete the results obtained in vivo. In these studies it was demonstrated that growth factors could have endocrine, autocrine or paracrine actions that modify gonadotropin-stimulated follicular growth and differentiation. FORTUNE et al. (2001) found that granulosa cells from the dominant follicle produce more estradiol in vitro than cells from subordinate follicles. Shortly after selection, dominant follicles have higher levels of mRNAs for gonadotropin receptors and steroidogenic enzymes.

In conclusion, the decline in FSH beginning after Day 2 of the heifer oestrous cycle causes differential alterations in FSH dependent growth factors and hormones within the cohort of preselection follicles, simultaneously inducing growth and enhanced estradiol producing capacity of the DF and atresia of subordinate follicles (MIHM et al., 1997).

\section{Dominance}

Follicles are functionally dominant (capable of ovulating after luteal regression) while they are still growing and early during their plateau in growth (FORTUNE et al., 1991). Follicles acquired ovulatory capacity at about $10 \mathrm{~mm}$, corresponding to about 1 day after the start of follicular deviation, but they required a greater LH dose to induce ovulation compared with larger follicles. It was speculated that acquisition of ovulatory capacity may involve an increased expression of LH receptors on granulosa cells of the dominant follicle and that this change may also be important for further growth of the dominant follicle (SARTORI et al., 2001).

Observations of GINTHER et al. (1997) indicate that the future dominant follicle cannot be identified reliably by either its diameter or estradiol production before the deviation in growth rates between the two largest follicles. Dominance appears to be maintained by negative feedback effects of products of the dominant follicle on circulating FSH. Selection and dominance are accompanied by progressive increases in the ability of theca cells to produce androgen and granulosa cells to aromatise androgen to estradiol. Dominant follicles grow to a much larger size than all the other follicles (from $8.5 \mathrm{~mm}$ at the end of selection to $12-20 \mathrm{~mm}$ ). This takes 3 to 4 days. LH pulses are indispensable for follicle development beyond $9 \mathrm{~mm}$ in diameter (GONG et al., 1996; KANITZ et al., 2001). Endocrine pattern of gonadotropins is followed by characteristic changes in follicles. Concentrations of estradiol-17 beta in follicular fluid and aromatase activity of follicular walls were higher in dominant follicles compared to subordinate follicles. Aromatase activity in first-wave dominant follicles was higher at Days 5 and 8 compared to Day 12 (BADINGA et al., 1992).

ASSEY et al. (1994) investigated the structure of oocytes aspirated from the dominant and its subordinate follicles. Therefore oocytes were aspirated from the dominant (largest) and two largest subordinate follicles and processed for transmission electron microscopy. Follicular fluids were analysed for concentrations of estradiol-17 beta (E2) and progesterone (P4). Dominant follicular growth was associated with increase in the concentration of E2 and P4 in the follicular fluid, which was E2-dominated. 
Subordinate follicles ceased growing at about days 3 - 4 and their follicular fluid had low E2:P4 ratio or was P4-dominated. Subordinate oocytes displayed degenerative features in their cumulus investment and nuclear activation and maturation especially after day 5.

The fate of the dominant follicle depends on function of the Corpus luteum. In the cases of elevated progesterone concentrations the dominant follicle becomes atretic due to the negative influence of the progesterone on pulsatility of LH secretion (IRERLAND et al., 2000). Under these circumstances functional dominance is lost some time between the early and late plateau phases (between days 7 and 9 of the oestrous cycle), while the follicle is still morphologically dominant (i.e. the largest follicle). Loss of dominance occurs after a decline in estradiol secretion (around day 6) of the dominant follicle of the first follicular wave (SUNDERLAND et al., 1994). A decrease in follicular estradiol and inhibin-A secretion is going in front of the new wave of follicular growth (GINTHER et al., 1996; MIHM et al., 2002).

From the available data following conclusions were drawn (ADAMS, 1999):

(1) follicles grow in a wave-like fashion; (2) periodic surges in circulating FSH are associated with follicular wave emergence; (3) selection of a dominant follicle involves a decline in FSH and acquisition of LH responsiveness; (4) periodic anovulatory follicular waves continue to emerge until occurrence of an LH surge; (5) within species, there is a positive relationship between the duration of the oestrous cycle and the number of follicular waves; (6) progesterone suppresses LH secretion and growth of the dominant follicle; (7) the duration of the interwave interval is a function of follicular dominance, and is negatively correlated with circulating FSH; (8) follicular dominance in all species is more pronounced during the first and last follicular waves of the oestrous cycle and (9) pregnancy, the prepubertal period and seasonal anoestrus are characterized by regular, periodic surges in FSH and emergence of anovulatory follicular waves.

\section{Final follicular maturation and ovulation}

Ovulation is induced by an increase in LH secretion (KANITZ et al., 2001). The LH surge triggers a biochemical cascade. The results of DIELEMAN and BLANKENSTEIN (1984, 1985) indicate that in preovulatory bovine follicles inhibition of aromatisation takes place at about $14 \mathrm{~h}$ after the preovulatory LH peak and progesterone concentrations increase before ovulation. Also progesterone receptor mRNA expression is upregulated specifically in the granulosa layer of bovine preovulatory follicles following the LH surge (CASSAR et al., 2002). Moreover results of DOW et al. (2002) show that mRNA expression and enzyme activity for both tPA and uPA are increased in a temporally and spatially specific manner in bovine preovulatory follicles after exposure to a gonadotropin surge. Increased plasminogen activator and plasmin activity may be a contributing factor in the mechanisms of follicular rupture in cattle. In sum the processes lead to the rupture of the preovulatory follicle, the expulsion of the oocyte and the formation of the Corpora luteum.

Local regulation of ovulation involves the interaction of $\mathrm{LH}$ and intrafollicular factors including steroids, prostaglandins, and peptides derived from endothelial cells, leukocytes, fibroblasts, and steroidogenic cells. An increase of prostaglandins 
( $\mathrm{PGE}_{2}$ and $\mathrm{PGF}_{2 \alpha}$ ) in follicular fluid of preovulatory follicles in the cow has been demonstrated by ALGIRE et al. (1992). Results from ACOSTA et al. (1998, 2000) suggest that interactions among ET-1, PGE2, and cytokines may have key roles in a local intermediatory/amplifying system of the LH- triggered ovulatory cascade in the bovine preovulatory follicle. FORTUNE al. (1993) found that oxytocin is also part of the LH induced biochemical cascade for ovulation.

In cattle PETERS and BENBOULAID (1998) investigated the occurrence of ovulation after $\mathrm{PGF}_{2 \alpha} / \mathrm{GnRH}$ application in some animals by means of ultrasound. Ovulation occurred between 24 to $48 \mathrm{~h}$ after $\mathrm{GnRH}$ injection. More recently, we examined the time of ovulation after $\mathrm{PGF}_{2 \alpha} / \mathrm{GnRH}$ application in heifers. Ultrasonographic examinations of ovaries were done every 6 hours during the periovulatory period. The mean interval from GnRH to ovulation was 25 to 33 hours. Our data and results from PETERS and BENBOULAID (1998) indicate, that ovulatory follicles have a diameter between 15 and $20 \mathrm{~mm}$. The results of KOT and GINTHER (1999) show, that the mean time from beginning to completion of evacuation of ovulatory follicles was $4.3 \pm 3.3 \mathrm{~min}$ (min. $6 \mathrm{~s}$; max. $14.5 \mathrm{~min}$.).

Some authors investigated results of A.I. in dependence on number of follicular waves or duration of dominance. AHMAD et al. (1997) found that pregnancy rate did not depend on number of follicular waves during oestrous cycle. In contrast to that TOWNSON et al. (2002) found that fertility was higher in cattle with three waves per cycle in comparison to cattle with two waves. The later findings seem to be in agreement with data from MIHM et al. (1994). They found that pregnancy rate was clearly dependent on duration/persistence of dominance of the ovulatory follicle in progesterone treated beef heifers. But is has to be considered that the duration/persistence of dominance in the treated animals was on average 10.8 days whereas it was on average 3.3 days in control animals.

\section{References}

ACOSTA, T.J.; MIYAMOTO, A.; OZAWA, T.; WIJAYAGUNAWARDANE, M.P.; SATO, K.:

Local release of steroid hormones, prostaglandin E2, and endothelin-1 from bovine mature follicles In vitro: effects of luteinizing hormone, endothelin-1, and cytokines. Biol. Reprod. 59 (1998), 437-443

ACOSTA, T.J.; OZAWA, T.; KOBAYASHI, S.; HAYASHI, K.; OHTANI, M.; KRAETZL, W.D.; SATO, K.; SCHAMS, D.; MIYAMOTO, A.:

Periovulatory changes in the local release of vasoactive peptides, prostaglandin $\mathrm{f}(2 \mathrm{alpha})$, and steroid hormones from bovine mature follicles in vivo. Biol. Reprod. 63 (2000), 1253-1261

ADAMS, G.P.:

Comparative patterns of follicle development and selection in ruminants. J. Reprod. Fertil. Suppl $\mathbf{5 4}$ (1999), 17-32

ADAMS, G.P.; MATTERI, R.L.; KASTELIC, J.P.; KO, J.C.; GINTHER, O.J.:

Association between surges of follicle-stimulating hormone and the emergence of follicular waves in heifers. J. Reprod. Fert. 94 (1992), 177-188

ADAMS, G.P.; EVANS, A.C.; RAWLINGS, N.C.:

Follicular waves and circulating gonadotrophins in 8-month-old prepubertal heifers. J. Reprod. Fertil. 100 (1994), 27-33

AHMAD, N.; TOWNSEND, E.C.; DAILEY, R.A.; INSKEEP, E.K.:

Relationship of hormonal patterns and fertility to ocurrence of two or three waves of ovarian follicles, before and after breeding, in beef cows and heifers. Anim. Reprod. Sci. 49 (1997), 13-28

ALGIRE, J.E.; SRIKANDAKUMAR, A.; GUILBAULT, L.A.; DOWNEY, B.R.:

Preovulatory changes in follicular prostaglandins and their role in ovulation in cattle. Can. J. Vet. Res. 56 (1992), 67-69 
AMIRIDIS, G.S.; ROBERTSON, L.; REID, S.; BOYD, J.S.; O'SHAUGHNESSY, P.J.; JEFFCOATE, I.A.: Plasma estradiol FSH and LH concentration after dominant follicle aspiration in the cow. Theriogenology 52 (1999), 995-1003

ASSEY, R.J.; HYTTEL, P.; GREVE, T.; PURWANTARA, B.: Oocyte morphology in dominant and subordinate follicles. Mol. Reprod. Dev. 37 (1994), 335-344

AUSTIN, E.J.; MIHM, M.; EVANS, A.C.O.; KNIGHT, P.G.; IRELAND, J.L.H.; IRELAND, J.J.; ROCHE, J.F.:

Alterations in intrafollicular regulatory factors and apoptosis during selection of follicles of the first follicular wave of the bovine estous cycle. Biol. Reprod. 64 (2001), 839-848

BADINGA, L.; DRIANCOURT, M.A.; SAVIO, J.D.; WOLFENSON, D.; DROST, M.; DE LA SOTA, R.L.; THATCHER, W.W.:

Endocrine and ovarian responses associated with the first-wave dominant follicle in cattle. Biol. Reprod. 47 (1992), 871-883

BAO, B.; GARVERICK, H.A.; SMITH, G.W.; SMITH, M.F.; SALFEN, B.E.; YOUNGQUIST, R.S.:

Changes in messenger ribonucleic acid encoding luteinizing hormone receptor, cytochrome P450-side chain cleavage, and aromatase are associated with recruitment and selection of bovine ovarian follicles. Biol. Reprod. 56 (1997), 1158-1168

BAO, B.; GARVERICK, H.A.:

Expression of steroidogenic enzyme and gonadotropin receptor genes in bovine follicles during ovarian follicular waves: a review. J. Anim. Sci. 76 (1998), 1903-1921

BEG, M.A.; BERGFELT, D.R.; KOT, K.; WILTBANK, M.C.; GINTHER, O.J.:

Follicular-fluid factors and granulosa-cell gene expression associated with follicle deviation in cattle. Biol. Reprod. 64 (2001), 432-441

BEG, M.A.; BERGFELT, D.R.; KOT, K.; GINTHER, O.J.:

Follicle selection in cattle: dynamics of follicular fluid factors during development of follicle dominance. Biol. Reprod. 66 (2002), 120-126

BELLMANN, A.:

Follikeldynamik und korrespondierende Hormonkonzentrationen beim Rind unter dem Einfluss eines GnRH-Agonisten in Depotformulierung (Decapeptyl ${ }^{\circledR}$ Depot). Univ. Leipzig, Diss., 2001

BERISHA, B.; SCHAMS, D.; KOSMANN, M.; AMSELGRUBER, W.; EINSPANIER, R.:

Expression and localisation of vascular endothelial growth factor and basic fibroblast growth factor during the final growth of bovine ovarian follicles. J. Endocrinol. 167 (2000), 371-382

BURKE, C.R.; DAY, M.L.; BUNT, C.R.; MACMILLAN, K.L.:

Use of a small dose of estradiol benzoate during diestrus to synchronize development of the ovulatory follicle in cattle. J. Anim. Sci. 78 (2000), 145-151

CASSAR, C.A.; DOW, M.P.; PURSLEY, J.R.; SMITH, G.W.:

Effect of the preovulatory LH surge on bovine follicular progesterone receptor mRNA expression. Domest. Anim. Endocrinol. 22 (2002), 179-187

CHAMBERLAIN, C.S.; SPICER, L.J.:

Hormonal control of ovarian cell production of insulin-like growth factor binding proteins. Mol. Cell Endocrinol. 182 (2001), 69-81

CROWE, M.A.; PADMANABHAN, V.; MIHM, M.; BEITINS, I.Z.; ROCHE, J.F.:

Resumption of follicular waves in beef cows is not associated with periparturient changes in folliclestimulating hormone heterogeneity despite major changes in steroid and luteinizing hormone concentrations. Biol. Reprod. 58 (1998), 1445-1450

DIELEMAN, S.J.; BLANKENSTEIN, D.M.:

Changes in oestrogen-synthesizing ability of preovulatory bovine follicles relative to the peak of LH. J. Reprod. Fertil. 72 (1984), 487-494

DIELEMAN, S.J.; BLANKENSTEIN, D.M.:

Progesterone-synthesizing ability of preovulatory follicles of cows relative to the peak of LH. J. Reprod. Fertil. 75 (1985), 609-615

DOW, M.P.; BAKKE, L.J.; CASSAR, C.A.; PETERS, M.W.; PURSLEY, J.R.; SMITH, G.W.:

Gonadotropin surge-induced up-regulation of the plasminogen activators (tissue plasminogen activator and urokinase plasminogen activator) and the urokinase plasminogen activator receptor within bovine periovulatory follicular and luteal tissue. Biol. Reprod. 66 (2002), 1413-1421

DRIANCOURT, M.A.:

Regulation of ovarian follicular dynamics in farm animals. Implications for manipulation of reproduction. Theriogenology 55 (2001), 1211-1239

EVANS, A.C.; ADAMS, G.P.; RAWLINGS, N.C.: 
Follicular and hormonal development in prepubertal heifers from 2 to 36 weeks of age. J. Reprod. Fertil. 102 (1994), 463-470

EVANS, A.C.; KOMAR, C.M.; WANDJI, S.A.; FORTUNE, J.E.:

Changes in androgen secretion and luteinizing hormone pulse amplitude are associated with the recruitment and growth of ovarian follicles during the luteal phase of the bovine estrous cycle. Biol. Reprod. 57 (1997), 394-401

FORTUNE, J.E.:

Ovarian follicular growth and development in mammals. Biol. Reprod. 50 (1994), 225-232

FORTUNE, J.E.; SIROIS, J.; TURZILLO, A.M.; LAVOIR, M. :

Follicle selection in domestic ruminants. J. Reprod. Fertil. Suppl 43 (1991), 187-198

FORTUNE, J.E.; VOSS, A.K.:

Oxytocin gene expression and action in bovine preovulatory follicles. Regul. Pept. 45 (1993), 257-261

FORTUNE, J.E.; KITO, S.; BYRD, D.D.:

Activation of primordial follicles in vitro. J. Reprod. Fertil. Suppl 54 (1999), 439-448

FORTUNE, J.E.; CUSHMAN, R.A.; WAHL, C.M.; KITO, S.:

The primordial to primary follicle transition. Mol. Cell Endocrinol. 163 (2000), 53-60

FORTUNE, J.E.; RIVERA, G.M.; EVANS, A.C.; TURZILLO, A.M.:

Differentiation of dominant versus subordinate follicles in cattle. Biol. Reprod. 63 (2001), 648-654

FRICKE, P.M.; AL HASSAN, M.J.; ROBERTS, A.J.; REYNOLDS, L.P.; REDMER, D.A.; FORD, J.J.:

Effect of gonadotropin treatment on size, number, and cell proliferation of antral follicles in cows.

Domest. Anim. Endocrinol. 14 (1997), 171-180

GIBBONS, J.R.; WILTBANK, M.C.; GINTHER, O.J.:

Functional interrelationships between follicles greater than $4 \mathrm{~mm}$ and the follicle-stimulating hormone surge in heifers. Biol. Reprod. 57 (1997), 1066-1073

GIBBONS, J.R.; WILTBANK, M.C.; GINTHER, O.J.:

Relationship between follicular development and the decline in the follicle-stimulating hormone surge in heifers. Biol. Reprod. 60 (1999), 72-74

GINTHER, O.J.:

Selection of the dominant follicle in cattle and horses. Anim Reprod. Sci. 60-61 (2000), 61-79

GINTHER, O.J.; KNOPF, L.; KASTELIC, J.P.:

Temporal associations among ovarian events in cattle during oestrous cycles with two and three follicular waves. J. Reprod. Fert. 87 (1989), 223-230

GINTHER, O.J.; WILTBANK, M.C.; FRICKE, P.M.; GIBBONS, J.R.; KOT, K.:

Selection of the dominant follicle in cattle. Biol. Reprod. 55 (1996), 1187-1194

GINTHER, O.J.; KOT, K.; KULICK, L.J.; WILTBANK, M.C.:

Sampling follicular fluid without altering follicular status in cattle: oestradiol concentrations early in a follicular wave. J. Reprod. Fertil. 109 (1997), 181-186

GINTHER, O.J.; BERGFELT, D.R.; KULICK, L.J.; KOT, K.:

Pulsatility of systemic FSH and LH concentrations during follicular- wave development in cattle. Theriogenology 50 (1998), 507-519

GINTHER, O.J.; BERGFELT, D.R.; KULICK, L.J.; KOT, K.:

Selection of the dominant follicle in cattle: establishment of follicle deviation in less than 8 hours through depression of FSH concentrations. Theriogenology 52 (1999), 1079-1093

GINTHER, O.J.; BERGFELT, D.R.; KULICK, L.J.; KOT, K.:

Selection of the dominant follicle in cattle: role of estradiol. Biol. Reprod. 63 (2000), 383-389

GINTHER, O.J.; BEG, M.A.; BERGFELT, D.R.; DONADEU, F.X.; KOT, K.:

Follicle selection in monovular species: Biol. Reprod. 65 (2001a), 638-647

GINTHER, O.J.; BERGFELT, D.R.; BEG, M.A.; KOT, K.:

Effect of LH on circulating oestradiol and follicular fluid factor concentrations during follicle deviation in cattle. Reproduction 122 (2001b), 103-110

GONG, J.G.; CAMPBELL, B.K.; BRAMLEY, T.A.; GUTIERREZ, C.G.; PETERS, A.R.; WEBB, R.:

Suppression in the secretion of follicle-stimulating hormone and luteinizing hormone, and ovarian follicle development in heifers continuously infused with a gonadotropin-releasing hormone agonist. Biol.Reprod. 55 (1996), 68-74

GOOD, T.E.; WEBER, P.S.; IRELAND, J.L.; PULASKI, J.; PADMANABHAN, V.; SCHNEYER, A.L.;

LAMBERT-MESSERLIAN, G.; GHOSH, B.R.; MILLER, W.L.; GROOME, N.; IRELAND, J.J.: Isolation of nine different biologically and immunologically active molecular variants of bovine follicular inhibin. Biol. Reprod. 53 (1995), 1478-1488

HSUEH, A.J.; EISENHAUER, K.; CHUN, S.Y.; HSU, S.Y.; BILLIG, H.:

Gonadal cell apoptosis. Recent Prog. Horm. Res. 51 (1996), 433-436 
IRELAND, J.L.; IRELAND, J.J.:

Changes in expression of inhibin/activin alpha, beta A and beta B subunit messenger ribonucleic acids following increases in size and during different stages of differentiation or atresia of non-ovulatory follicles in cows. Biol. Reprod. 50 (1994), 492-501

IRELAND, J.L.; GOOD, T.E.; KNIGHT, P.G.; IRELAND, J.J.:

Alterations in amounts of different forms of inhibin during follicular atresia. Biol. Reprod. 50 (1994), 1265-1276

IRELAND, J.J.; MIHM, M.; AUSTIN, E.; DISKIN, M.G.; ROCHE, J.F.:

Historical perspective of turnover of dominant follicles during the bovine estrous cycle: key concepts, studies, advancements, and terms: J. Dairy Sci. 83 (2000), 1648-1658

KANEKO, H.; TAYA, K.; WATANABE, G.; NOGUCHI, J.; KIKUCHI, K.; SHIMADA, A.; HASEGAWA, Y.: Inhibin is involved in the suppression of FSH secretion in the growth phase of the dominant follicle during the early luteal phase in cows. Domest. Anim. Endocrinol. 14 (1997), 263-271

KANITZ, W.; BRÜSSOW, K.P.; BECKER, F.; TORNER, H.; SCHNEIDER, F.; KUBELKA, M.; TOMEK, W.: Comparative aspects of follicular development, follicular and oocyte maturation and ovulation in cattle and pigs. Arch. Anim. Breed., Dummerstorf 44 (2001), 9-23

KNOPF, L.; KASTELIC, J.P.; SCHALLENBERGER, E.; GINTHER, O.J.:

Ovarian follicular dynamics in heifers: test of two wave hypothesis by ultrasonically monitoring individual follicles. Dom. Anim. Endocr. 6 (1989), 111-119

KOT, K.; GINTHER, O.J.:

Ultrasonic characterization of ovulatory follicular evacuation and luteal development in heifers. J. Reprod. Fert. 115 (1999), 39-43

KULICK, L.J.; KOT, K.; WILTBANK, M.C.; GINTHER, O.J.:

Follicular and hormonal dynamics during the first follicular wave in heifers. Theriogenology 52 (1999), 913-921

LUCY, M.C.:

Regulation of ovarian follicular growth by somatotropin and insulin- like growth factors in cattle. J. Dairy Sci. 83 (2000), 1635-1647

MELVIN, E.J.; LINDSEY, B.R.; QUINTAL-FRANCO, J.; ZANELLA, E.; FIKE, K.E.; VAN TASSELL, C.P.; KINDER, J.E.:

Circulating concentrations of estradiol, luteinizing hormone, and follicle-stimulating hormone during waves of ovarian follicular development in prepubertal cattle. Biol. Reprod. 60 (1999), 405-412

MIHM, M.; BAGUISI, A.; BOLAND, M.P.; ROCHE, J.F.:

Association between the duration of dominance of the ovulatory follicle and pregnancy rate in beef heifers. J. Reprod. Fertil. 102 (1994), 123-130

MIHM, M.; GOOD, T.E.; IRELAND, J.L.; IRELAND, J.J.; KNIGHT, P.G.; ROCHE, J.F.:

Decline in serum follicle-stimulating hormone concentrations alters key intrafollicular growth factors involved in selection of the dominant follicle in heifers. Biol. Reprod. 57 (1997), 1328-1337

MIHM, M.; AUSTIN, E.J.; GOOD, T.E.; IRELAND, J.L.; KNIGHT, P.G.; ROCHE, J.F.; IRELAND, J.J.: Identification of potential intrafollicular factors involved in selection of dominant follicles in heifers. Biol. Reprod. 63 (2000), 811-819

MIHM, M.; AUSTIN, E.J.:

The final stages of dominant follicle selection in cattle. Domest. Anim. Endocrinol. 23 (2002), 155-166

MIHM, M.; CROWE, M.A.; KNIGHT, P.G.; AUSTIN, E.J.: Follicle wave growth in cattle. Reprod. Domest. Anim. 37 (2002), 191-200

MURPHY, M.G.; BOLAND, M.P.; ROCHE, J.F.: Pattern of follicular growth and resumption of ovarian activity in post- partum beef suckler cows. J. Reprod. Fertil. 90 (1990), 523-533

NILSSON, E.; PARROTT, J.A.; SKINNER, M.K. :

Basic fibroblast growth factor induces primordial follicle development and initiates folliculogenesis. Mol. Cell Endocrinol. 175 (2001), 123-130

NILSSON, E.E.; KEZELE, P.; SKINNER, M.K.:

Leukemia inhibitory factor (LIF) promotes the primordial to primary follicle transition in rat ovaries. Mol. Cell Endocrinol. 188 (2002), 65-73

PARROTT, J.A.; SKINNER, M.K.: Kit ligand actions on ovarian stromal cells: effects on theca cell recruitment and steroid production. Mol. Reprod. Dev. 55 (2000), 55-64

PETERS, A.R.; BENBOULAID, M.: Studies on the timing of ovulation after synchronisation treatments in cattle. Reprod. Dom. Anim. 33 (1998), 313-315 
PORTER, D.A.; HARMAN, R.M.; COWAN, R.G.; QUIRK, S.M.:

Relationship of Fas ligand expression and atresia during bovine follicle development. Reproduction 121 (2001), 561-566

RAJAMAHENDRAN, R.; TAYLOR, C.:

Follicular dynamics and temporal relationship among body temperature, oestrus, the surge of luteinizing hormone and ovulation in Holstein Heifers treated with norgestomet. J. Reprod. Fert. 2 (1991), 461-467

RHODES, F.M.; DE'ATH, G. ; ENTWISTLE, K.W. :

Animal and temporal effects on ovarian folicular dynamics in Brahman heifers. Anim. Reprod. Sci. 38 (1995), 265-277

ROCHE, J.F.; AUSTIN, E.J.; RYAN, M.; O'ROURKE, M.; MIHM, M.; DISKIN, M.G.:

Regulation of follicle waves to maximize fertility in cattle. J. Reprod. Fertil. Suppl 54 (1999), 61-71

SARTORI, R.; FRICKE, P.M.; FERREIRA, J.C.; GINTHER, O.J.; WILTBANK, M.C.:

Follicular deviation and acquisition of ovulatory capacity in bovine follicles. Biol. Reprod. 65 (2001), 1403-1409

SAVIO, J.D.; KEENAN, L.; BOLAND, M.P.; ROCHE, J.F.:

Pattern of growth of dominant follicles during the oestrous cycle of heifers. J. Reprod. Fertil. 83 (1988), 663-671

SCHAMS, D.; BERISHA, B.; KOSMANN, M.; AMSELGRUBER, W. M.:

Expression and localization of IGF family members in bovine antral follicles during final growth and in luteal tissue during different stages of estrous cycle and pregnancy. Domest. Anim Endocrinol. 22 (2002), 51-72

SIROIS, J.; FORTUNE, J.E.:

Ovarian follicular dynamics during the oestrous cycle monitored by real-time ultrasonography. Bio. Reprod. 39 (1988), 308-317

SUNDERLAND, S.J.; CROWE, M.A.; BOLAND, M.P.; ROCHE, J.F.; IRELAND, J.J.:

Selection, dominance and atresia of follicles during the oestrous cycle of heifers. J. Reprod. Fertil. 101 (1994), 547-555

TAYLOR, C.; RAJAMAHENDRAN, R.:

Follicular dynamics and corpus luteum growth and function in pregnant versus nonpregnant cows. J. Dairy Sci. 74 (1991), 115-121

TOWNSON, D.H.; TSANG, P.C.; BUTLER, W.R.; FRAJBLAT, M.; GRIEL, L.C.,JR.; JOHNSON, C.J.; MILVAE, R.A.; NIKSIC, G.M.; PATE, J.L.:

Relationship of fertility to ovarian follicular waves before breeding in dairy cows. J. Anim Sci. 80 (2002), 1053-1058

WEBB, R.; GOSDEN, R.G.; TELFER, E.E.; MOOR, R.M.:

Factors affecting folliculogenesis in ruminants. Animal Science 68 (1999), 257-284

YUAN, W.; BAO, B.; GARVERICK, H.A.; YOUNGQUIST, R.S.; LUCY, M.C.:

Follicular dominance in cattle is associated with divergent patterns of ovarian gene expression for insulin-like growth factor (IGF)-I, IGF-II, and IGF binding protein-2 in dominant and subordinate follicles. Domest. Anim Endocrinol. 15 (1998), 55-63

Received: 2003-02-03

Accepted: 2003-03-04

Authors address

VR PD Dr. habil. WILHELM KANITZ

Department of Reproductive Biology,

Research Institute for the Biology of Farm Animals,

Wilhelm-Stahl-Allee 2

D-18196 Dummerstorf

Germany 